ベンゼン4)がみられないことから（3）のようにメチル 遊離基とベンジル遊離基との反応がメチル遊離基とトル エンとの反応より可能性が多いと考兄られる。

$p$-キノジメタンの電子状態の計算は前派2) に報告し 太。气礼によると最も安定な基準状態は ${ }^{1} A_{1 g}$ であるが, ${ }^{3} B_{3 u}$ とのエネルギー差が約 $9.6 \mathrm{kcal}$ であるため, 各々 ○実験に扔いて温度が $800^{\circ} \mathrm{C}$ 乃至 $900^{\circ} \mathrm{C}$ ではるところ から生成した $p$-キノジメタンのらち数\%は三重項状態 にあると推定される。文 ${ }^{1} A_{1 g}$ にしてる ${ }^{3} B_{3 u}$ でも両方の 从チレン基の free valency の佰は大きく ${ }^{5)}(0.92$ と1.13) 重合し易いことが判る。これは $p$-キノジメタンが师 $\mathrm{B}$ をでてからすぐ溶媒に不溶性の重合物が生成する実験事 笑之一致する。又低い励起状態は ${ }^{1} B_{3 u}$ で女りり ${ }^{1} A_{1} g$ と の汸ネル゙ー差は $4.4 \mathrm{e} . \mathrm{V}$. でその間の転移は許容転移 そなるが，観测された吸収は $2740 〜 2770 \AA(4.5$ e.V.)で $\left.\log \varepsilon \approx 3 \sim 4^{2}\right)$ でるので, この吸収は ${ }^{1} A_{1 g} \longleftrightarrow{ }^{1} B_{3 u}$ の 軾移であることが推定される。

$p$-未ノジメタン, $p$-キノンは蔧造的にはキノン型でメ チレン基か酸素原子かの相違で希るのみで岁る故, 各々 ○電子状態は互によく似ているはずで山る。 吸収スペクトルは $2450 \AA(\log \varepsilon \fallingdotseq 4.5), 2900 \AA(\log \varepsilon \fallingdotseq$ $3.0), 4450 \AA(\log \varepsilon=1.4)$ ○つ嵌り, $p$-キノジメタ ン○ $2740 \sim 2770 \AA$ の吸收は $2900 \AA$ の吸収代対応して いる。 $2450 \AA$ ○吸收に対広している四収が $p$-キノジメ タッにも同様に在すると考完られるが実験的には $p$-キ

4）岩井,“熱分解法によるスチロー几同族体の合成”(1949).誠女堂 新光社.

5) C. A. Coulson, D. P. Craig, A. Maccoll, MDE. A. Pullman, Discuss. Faraday Soc. “The Labile Molecule” 36 (1947).
シレンの吸収に重なって測定は困難でむる。又 $4450 \AA$ の吸収は $p$-キノジメタンには観測されず,これは酸素原 子の非結合電子が励起 $\pi$ 電子準位へ転移 $\left(n \rightarrow \pi^{*}\right.$ 転移) することによるもとの推定しうる。これは他の実験事 笑, 即ち遷移確率の計算 ${ }^{6)}$, 置換基の影響7), 溶媒効果 ${ }^{3)}$, 振動带の広がり ${ }^{8)}$ 等と一致する。

\section{V. 結論}

ペンゼン，トルエン，p-，O-キシレン，エチルベンゼ ン，イソプロピルベンゼン，塩化ベンジルなどの芳香族 分子を試料として気体の熱反店を行い，反応中或いは反 応直後の吸収スペクトルをとった。この結果熱反応によ って生ずる安定な分子として,トルエンからアントラセ ン, スチレン，ベンゼンを $0-, p$-キシレンからアントラ セン, o-, p-メチルスチレン, スチレン, トルエン， だ ンゼン，又ェチルベンゼン妓びイソプロピルベンゼンか らスチレンが, 又塩化ベンジルからアントラャン，スチ レンが確められだ。これらの生成機構に関しわれわれの 実験事実区び Szwarc の実験事実より考察した。又 $p$ キシレンから 2740 2 $2770 \AA$ の新しい罗収を示す物質が 生成することを認め, この物質が $p$-キノジメタンで品 ることを確めた。p-キノジメタンの電子状態と吸収スぺ クトルとの関係及び $p$-キノンの電子状態との比較を研 究した。

6) H. L. MacMurry, J. Chem. Phys. 9, 231, 241 (1941).

7) 馬場, 本誌 72, 341 (1951).

8) M. Kasha, Discuss. Faraday Soc. "Spectroscopy and Molecular Structure" 14 (1950); H. McConnell, J. Chem. Phys. 20, 700 (1952); 長倉, 久保山, 本誌 74, 499 (1953).

(佐贺大学交理学部化学教空，佐贺术外) (昭和 28 年11月 24 日受理)

\title{
イオン交換樹脂と E.T.A. 試藥による天然水中の硫酸根の定量について
}

\author{
飯 盛 喜 代 春
}

\section{緒}

\section{論}

エチレンジアミンテトラ酢酸(E.T.A.)が, Schwarzen・ bach $^{1}$ により，水の硬度測定に応用されて以来，E.T.A. 試薬こついて多くの関心がよせられた。

Munger ${ }^{2)}$ 等は本試薬を使用して, 硫酸イオンの容量

1) W. Biedermann, G. Schwarzenbach, Chimia 2, 56 (1948).

2) J. R. Munger, R. W. Nippler, R. S. Ingols, Anal. Chem.

$22,1455(1950)$.
分析法を提唱した。即ち一定量の過㮃のバリウムイオン を加えて，硫酸バリウムを完全伛沈激せしめ，過剩のバ リウムイオンをE.T.A.試薬で滴定して, 硬度と其に, 硫酸イオンを間接的に定量した。又坂口氏等3 はE.T.A. 試薬を用いて，温泉中の硫酸イオンの定量を行った。そ こで著者は陽イオン交換樹脂を用いて陽イオンを交換吸

3）坂口, 田口, “E.T.A. 試藥を用いる䟽酸根の谪定法”日本分析 化学会第 1 年会報告 (1952). 
着4)5)6)させて分離除去ゔしたのち，E.T.A.試薬を用い て硫酸イオンの間接定量を行い，Munger 等の方法によ るものと大体一致した值を得たので，これを用いて天然 水中の硫酸イオンの定量を行い，徉来行われていた重量 法と比較した。

\section{実 験 条 件}

\section{(A) 拭薬}

(1) 緩衝溶液——特級热化アンモニウム $67.5 \mathrm{~g}$ を 特級アンモニア水 $570 \mathrm{cc}$ にとかし, 水を加穴て $1 l$ K する。

(2) 指示薬一一片オクロムプラック T.CE.B. T.) $4.5 \mathrm{~g}$ をメタノール $100 \mathrm{cc}$ に溶解する。

(3) 塩化バリウム標準溶液——再結晶した盐化バリ ウムから 0.01 mole のものをつくる。

(4) 掹化マグネシウム橴準溶液——篮化マグネシウ ムを水にとかし，0.01 mole のものをつくる。

(5) $\mathrm{E} \cdot \mathrm{T} \cdot \mathrm{A} \cdot$ 試薬—E.T.A.試薬を約 $3.9 \mathrm{~g}$ と り, 水て $1 l$ にとかして, 上記の塩化バリウム慗集溶液 で標定する。

$\mathrm{E} \cdot \mathrm{T} \cdot \mathrm{A} \cdot$ 試薬の標定：壏化バリウム䌉準溶液を $10 \mathrm{cc}$ とり，これに水を加穴て $100 \mathrm{cc}$ にする。これに $1 \mathrm{cc}$ の 䏅化マグネシウム溶液を加穴, 更に $3 \mathrm{cc}$ の緩衝溶液を 加えて, 次に指示薬 E.B.T.を 5 滴加えてビウレッ トより E・T・A. 試薬を滴下して, 赤色が猆色に变り, 全く赤昧がなくなった点を終点とする。ここで盐化マグ ネシウムを加えるのは，バリウムイオンと E・B・T・と が，マグネジウムイオンと E.B.T・とのように, 終点を 指示するほど安定な着色錯化合物を生成せず，反応の終 点が不明瞭で孫るために，マグネシウムによって鋭敏な 变色を示すためで希る。壏化マグネシウム溶液 $1 \mathrm{cc}$ と 作用する $\mathrm{E} \cdot \mathrm{T} \cdot \mathrm{A}$.試薬の量を差引梳ば, 全滴定量より パリウムイオンと作用し、た $\mathrm{E} \cdot \mathrm{T} \cdot \mathbf{A}$.試薬の量がわかる。 この際マグネシウムのみ存在する場合に比して，少し变 色の鋭敏度は減少するようで安る。

\section{(B) イオン交換樹脂柱}

イオン交換樹脂は Amberlite IR-120 を用いた。こ れを荒く砕き，50 cc 容量のビウレットに充填する。即 ちビウレットの最下部にガラス綿，その上にイオン交捛 樹脂（容積約 $20 \mathrm{cc}$ )，更に‡の上にガラス綿を詰める。

4) G. E. Boyd, J.Schubert, A. W.Adamson, J. Am. Chem. Soc. 69, 2818 (1947).

5) 吉野, 本誌 72, 457 (1951).

6) 本田, 本誌 71, 118 (1950).

7) 武藤, 本憙 72, 976 (1951).
試料を樹脂柱の上部より流し入れ，樹墽を通して，2 秒間に 3 滴位の速度で滴下する。滴下速恔はビウレット の括栓で目由に調節亚来る。実験の前後に，E・T.A. 試薬と作用する陽イオンが交势吸管され，滴下液中に存 在しないことを確めた。な打樹㫨の邽生に洆溜しな約 $2 \mathrm{~N}$ の㷪酸を用いた。

\section{(C) 実験操作}

試料（硫酸イオンを含んだもの）をビウレットよりと り，イオン交換樹脂柱を通す。初めに滴下液約 $50 \mathrm{cc}$ 位 はすてる。後滴下液を $100 \mathrm{cc}$ とりこの場合相当酸性 になっている)，これに酢酸(永酢酸を水で 10 倍に薄め たもの)の $1 \mathrm{cc}$ を加穴, 者沸して遊離宸酸及び或酸盐 を分解除去し， 0.01 mole 壏化バリウム標淮溶液 $10 \mathrm{cc}$ を加穴, 更に 2〜3 分間煮沸して硫酸バリウムの沈澱を 完成する。冷却後, 盐化マグネシウム溶液を $1 \mathrm{cc}$ 加六, 更に緩衝溶液を $3 \mathrm{cc}$, 指示薬を 5 滴加えて, E.T.A. 試薬で滴定する。以上の操作は上記 $\mathrm{E} \cdot \mathrm{T} \cdot \mathrm{A}$.試薬標定 と同様に行う。往って過剩のバリウムを定量して硫酸イ オンの量を間接的に求める。

\section{(D) 実験結果}

(1) 硫酸イオンのみの埸合一硫酸イオンの量を整 它て，これに一定量の嫶化バリウムを加穴て，過剩のバ リウムを $\mathrm{E} \cdot \mathrm{T} \cdot \mathrm{A} \cdot$ 試薬で滴定して, E.T.A. 試薬凹 量と硫酸イオンの量との関係を求めて見た。試料として は稀硫酸 $\left(0.9 \mathrm{mg} \mathrm{SO}{ }^{2-} / 10 \mathrm{cc}\right)$ を 5 90 cc ๑間つ 様々の容積をとり, 各々について上記硫酸イオンの定 量の方法を行った。この場合イオン交换樹脂を通し太場 合と，通さなかった坋合と闭方行って見たが，硫酸イオ ンの量は，耐方の塕合とも大体において一致した值を示 している。E.T.A. 試薬の使用量と硫酸イオンの量と は比例的な関係を示し，これを区示すれば䈆1羽のよう になる。

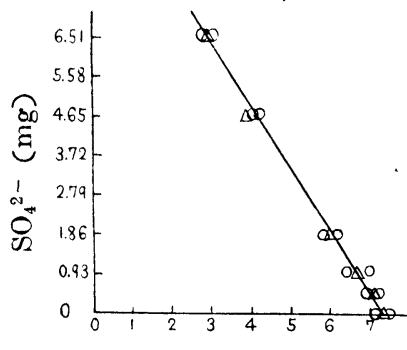

$\mathrm{E} \cdot \mathrm{T} \cdot \mathrm{A} \cdot(\mathrm{cc})$

○イオン交換樹脂を使用しない場合

$\triangle 1$ イン交換樹脂を通した場合

第 1 図 


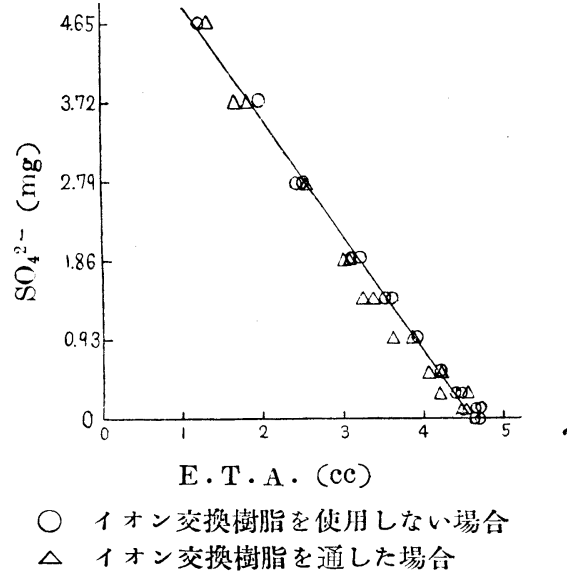

第 2 図

(2) マグネシウムイオン，カルシウムイオンと硫酸

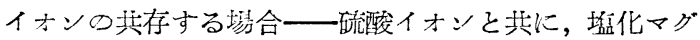
ネシウムを約 $200 \mathrm{mg} / l$, 奴び盐化カルシウムを約 $50 \mathrm{mg} / l$ 含むような試料を作り，これを上記( 1 )と全く同様な方 法で硫酸イオンの定量を行った。この坋合も(1)と同様 殆んど正確に，硫酸イオンと $\mathrm{E} \cdot \mathrm{T} \cdot \mathrm{A}$.試薬の使用量と は直鼣的な関係を示している。これを図示すれば第2困 のようになる。この㭙イオン交換樹脂を通してマグネシ ウムイオン，カルシウムイオンを除去して定量した場合 と，イオン交換樹脂を通さずに定量した募合と殆んど一 致した値を示している。イオン交換樹脂を通さない試料 にはマグネシウムイオオン，カルシウムイオンを含まず， 硫酸イオンのみを含さ。上記( 1 )，(2)の実験結果より 考えると, 硫酸イオンとイオン交㨐樹脂, マグネシウム イオン,カルシウムイオンとの影響はないものと思われ 万。

（3）試料として佐賀県佐賀郡西与賀村小学校井戸の 水を用い，次の 2 方法で淳差の原因とその大きさを研究 した。

イ）供試量新化法：イオン交换樹脂を通して，上記 の方法によって硫酸イオンの定量を供試量の $50 \mathrm{cc}$, $100 \mathrm{cc}, 150 \mathrm{cc}$ の各々について行った。その結果を珝示 すれてば，第3困Iのようになり，殆んど正確な原点を通 る $45^{\circ}$ の勾配をもった值線となる。こ北により供試量

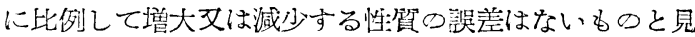

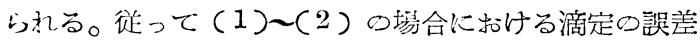
より大きな㽬差はないものと見られる。

口) 微量添加法：次に上記試料に硫酸イオンの微量 ○添加を行って見た。即ち供試量 $50 \mathrm{cc}, 100 \mathrm{cc}, 150 \mathrm{cc}$ ○各々に硫酸イオン $0.9 \mathrm{mg}$ を加光，上記の通りの方法

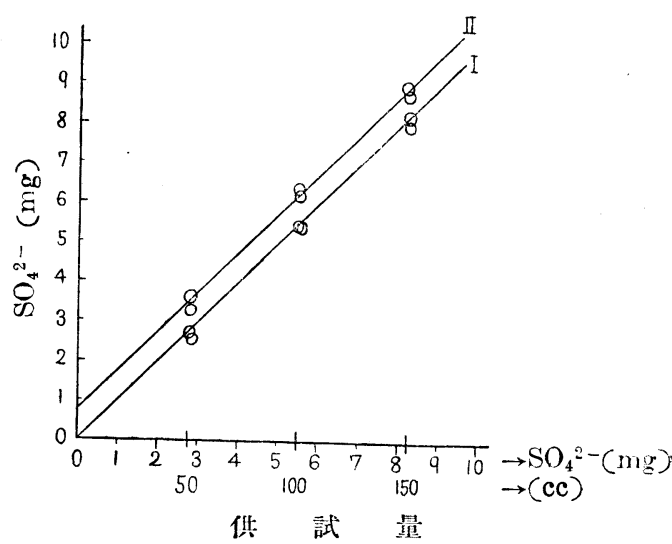

I：供試量のみの場合

II：供試量に微量添加の場合

第 3 図

で硫酸イオンの定量を行った。これを四示すれば第 3 困 II となり（イの場合の直線と平行な宜線となる。

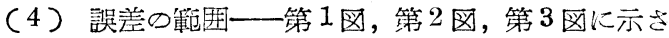
れた如く，バラッキの莗囲は(1)，(2)，(3)の圽合に

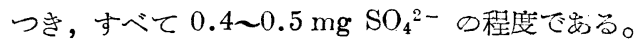

\section{(E) 他の分析法との比較}

種々の試料につき重量法, Munger の法, 本法のそれ ぞれの方法で天然水中の硫酸イオンの定量を行った。

\section{(1) 分析法}

イ）重量分析法 ${ }^{8) ：}$ 試料 $500 \mathrm{cc}$ をとって，これに

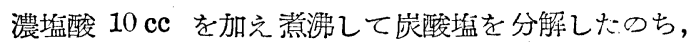
10\%塭化バリウム溶液を 10２0 cc 加える（硫酸イオン の量により適当に加え，塩化バリウムが過剩になるよう に加穴るつ。そして硫酸バリウムの沈搌を完成して,灼熱 し科量する。

) Munger $\Phi^{2}{ }^{2}$ :

(a) 試料 $50 \mathrm{cc}$ k緩衝溶液 $1 \mathrm{cc}$ と $\mathrm{E} \cdot \mathrm{B} \cdot \mathrm{T}$.指示薬 5 滴加え， E.T.A. 試薬で滴定して，試料中の硬度を 求める。

(b) 塭酸 $(0.1 \mathrm{~N})$ 標準溶液で試料のアルカリ度を測 定する。

(c) 別に試料 $50 \mathrm{cc}$ をとり，アルカリ相当量或いは やや過剩の壏酸を加穴, 一且煮沸する。次に硫酸イオン の量に応じて $5 \mathrm{cc}$ 10 cc の塩化バリウム栖潐溶液を加 之, 数分間復沸後泠却し緩衝溶液 $10 \mathrm{cc}$ と指示薬 5 滴を 加光 $\mathrm{E} \cdot \mathrm{T} \cdot \mathrm{A} \cdot$ 試薬で滴定する。このとき終点を明瞭 ならしめるため盐化マグネシウム溶液 I c c を加六る。

8) 奥野, “化学実鈳学, 第 1 部, 10 分析化学 II” p. 335 (1942) (河出春房) 
しかる特は次の式以よって硫酸イオンの量が求められ る。

$$
(H+B+M-T) \times 48 \times \frac{1000}{50}=\mathrm{SO}_{4}{ }^{2-} \text { p.p.m. }
$$

$H ：$ 余硬度ほ测定するに要したE.T.A。 試薬ひミり当量数

$B ：$ 加元られた塩化バリウムのミリ当量数

$M:$ 程化マグネシウムのミリ当政数

I': バリウムイオン，マグネシウムイオン 及ア゙全硬度に対して用いら扎た $\mathrm{E} \cdot \mathrm{T}$ 。 $A \cdot$. 試薬め全ミリ当量数

(2) 結果を第1表，区び第 4 図に示す。以上の実験 で判るように，3方法とも大体一致した值を示している。 ここで更に詳しくその値の差を見るならば，大体に捣い て本法は重量法に比して, 幾分多く出る傾向があり, IIunger の法は幾分少なく出るようで山る。本法の方 が，より重量法の值に幾分近い值を与完るようである。

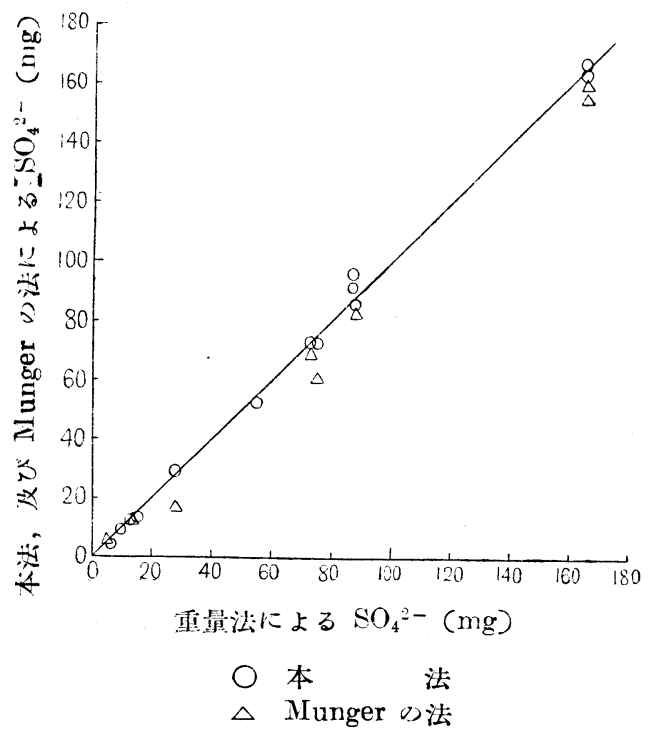

第 4 欧
第 1 表

\begin{tabular}{|c|c|c|c|c|}
\hline 实 験 試 料 & $\mathrm{pH}$ & 本法 & 重量法 & $\underset{\infty}{\text { Munger }}$ \\
\hline 西与賀小学校井戸 & 6.6 & 53 & 53 & 54 \\
\hline ○有 明 敏 & 6.0 & 1915 & 1901 & 1884 \\
\hline 武 雄 温 泉 & 7.0 & 10 & 10 & 0 \\
\hline ○痁 津 湾 & 6.6 & 2550 & 2585 & .550 \\
\hline ○相 応 (満 潮) & 6.6 & 1312 & 1313 & 1314 \\
\hline 今津(本)主川)厈潮 & 6.3 & 13 & 14 & 13 \\
\hline 八田江 & 6.5 & 29 & 28 & Iti \\
\hline 六 觕 川 & 6.4 & 73 & 73 & 69 \\
\hline 大町町井 戸 & 6.6 & 164 & 165 & 156 \\
\hline 西川副村井 斤 & 7.6 & 74 & 75 & 61 \\
\hline 小川副村井巨 & 7.0 & 86 & 88 & 83 \\
\hline 杵島荻碳坑內水 & 7.6 & 168 & 165 & 161 \\
\hline 西与賀小学校井戶 II & 6.6 & 53 & 55 & - \\
\hline 同上卭 & 6.5 & 13 & 15 & - \\
\hline 西与賀村 井戶 I & 6.0 & 97 & 87 & - \\
\hline 同 上 井戸 II & 6.5 & 92 & 88 & - \\
\hline
\end{tabular}

O印は図示せず・数字は $\mathrm{SO}_{4}{ }^{2-} \mathrm{mg} / \mathrm{l}$ を示す。

ヌカルシウム, マグネシウム等の多い試料, 即ち硬度 の高いるの, 双海水の始くナトリウム等の非常に多量存 在するときは，これをそのままイオン交換樹脂柱を通す と，充填した樹脂の交換容量以上になり，不都合でむる ので，かかる淕合は，適当にうすめて用いた。カルシウ ム，マグネシウム等が極めて多く, 硫酸イオンが極めて 少ない試料は，この方法で測定が困難でむるが，これは 他の方法 (重量法)でも同椂で璐る。本実験に用いた天 然水は十分定量出来た。

終りにあたり，本实験に関して，終始御愁切なる御指 導を賜わった九州大学り石森賞太郎助教授に深く感謝す る。又本实験に使川した1 オン交换樹脂 Amberlite IR120 を提買して戴いた立教大学の本川雅健助教授に厚く 感謝する。

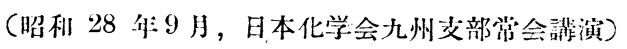


第 2 表 放電電压の影響 (条件及び結果)

\begin{tabular}{|c|c|c|c|c|}
\hline $\begin{array}{c}\text { 条件及び 放電電圧 } \\
\text { 結果 }\end{array}$ & 10 & 15 & 20 & 25 \\
\hline 一次電 圧 $(V)$ & 40 & 60 & 80 & 100 \\
\hline - 次，電 流 $(A)$ & 1.59 & 2.60 & 3.28 & 3.90 \\
\hline 放 電 電 流 $(\mathrm{m} A)$ & 9.2 & 13.2 & 17.6 & 21.8 \\
\hline 電管温度 $\left({ }^{\circ} \mathrm{C}\right)$ & $20 \sim 30$ & $30 \sim 40$ & $35 \sim 45$ & $540 \sim 50$ \\
\hline 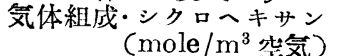 & 3.10 & 3.10 & 3.10 & 3.10 \\
\hline $\begin{array}{l}\text { 気 体 温 }\left(^{\circ} \mathrm{C}\right) \\
\text { 気体流速 }(\mathrm{Vol} / \mathrm{min} / \mathrm{Vol})\end{array}$ & $\begin{array}{c}16 \\
1.0\end{array}$ & $\begin{array}{l}15 \\
1.0\end{array}$ & $\begin{array}{l}15 \\
1.0\end{array}$ & $\begin{array}{l}15 \\
1.0\end{array}$ \\
\hline 気体圧方 $(\mathrm{mmHg})$ & 768 & 768 & 768 & 768 \\
\hline 放 電 時 間 (hr) & 6.0 & 5.0 & 2.5 & 3.0 \\
\hline 使用シクロヘキサン量(g) & $81.7_{0}$ & $68.0_{9}$ & $34.0_{4}$ & $40.8_{5}$ \\
\hline 全生成物 量 $(\mathrm{g})$ & 10.15 & 19.41 & 12.14 & 22.13 \\
\hline $\begin{array}{l}\text { 反応率 }(\%) \\
\text { 生成物内訳 }\end{array}$ & 12.4 & 28.6 & 35.6 & 54.3 \\
\hline (主生成物 (収率) (\%) & 71.9 & 67.9 & 63.1 & 60.0 \\
\hline 有機酸(アジピン酸) (\%) & 8.3 & 13.0 & 20.8 & 19.3 \\
\hline 蒸 溜 残 渣 (\%) & 19.8 & 19.1 & 16.1 & 20.7 \\
\hline 時間当り生成量 $(\mathrm{g} / \mathrm{hr})$ & 1.69 & $3.8_{8}$ & $4.8_{5}$ & $7.3_{8}$ \\
\hline
\end{tabular}

管の長さをそれぞれ適宜に率化して区応率区び収率に現 われる影響を調べ次のような結果を得心。

\section{放電電压の影響}

使用した放電管の放電開始電圧は約 $7.0 \mathrm{kV}$ 程度で岁, るため，之和以上の $10 ， 15 ， 20,25 \mathrm{kV}$ の各電圧值に 㸫いて他の条件を第 2 表の如く活涪一定として行った。 放電管温度が電圧上昇化伴ない增加するのは管材料でま るガシスの誘電加蓺の增加によるものと侾えられ，反応 に影響を与完てはいない。気体流速 $1 \mathrm{Vol} / \mathrm{min} / \mathrm{Vol}$ は

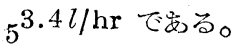

その結果を第 2 表に併せて揭げた。即ち電圧増加に伴 ない反応率は比例的に著しく增加し, 主生成物の収率は これに比し漸減する。収率減少の原因はアジピン酸の増 加によるように思利秃た。単位㭙閒当りの全生成物量は 電圷に比例し反応率の場合々同椂でむる。

\section{気体流速及び気体組成の影墽}

流速を 1，2，3，4 Vol $/ \mathrm{min} / \mathrm{Vol}$ と変化し,混合気体 中のシクローキサン濃度を $3.32 \sim 3.70 \mathrm{~mole} / \mathrm{m}^{3}$ air 程 度の低濃度と $4.55 \sim 5.73 \mathrm{~mole} / \mathrm{m}^{3}$ air 程度の高濃度の 場合について実験し心。前者の条件及び結果を第 3 表 に，後者を第 4 表にそ机ぞれ揭げた。

そっ結果, 区応率は洿速に逆比例して著しく減少し,
筑3表完体流速の影響 (シクローキサン低激度の場合)

\begin{tabular}{|c|c|c|c|c|}
\hline $\begin{array}{c}\text { 条件及 } \\
\text { び結果 } \\
\text { 気体流速 }\end{array}$ & 1.0 & 2.0 & 3.0 & 4.0 \\
\hline 一次電 圧 (V) & 100 & 100 & 100 & 100 \\
\hline 一次需 流 $(A)$ & 4.0 & 3.9 & 3.9 & 4.3 \\
\hline 放 電 電 圧 $(\mathrm{kV})$ & 25 & 25 & 25 & 25 \\
\hline 放 電 電 流 $(\mathrm{mA})$ & 20.4 & 20.6 & 20.3 & 21.0 \\
\hline 放雷管温度 $\left({ }^{\circ} \mathrm{C}\right)$ & $45 \sim 55$ & $45 \sim 55$ & $40 \sim 50$ & $40 \sim 50$ \\
\hline 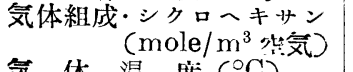 & 3.42 & 3.38 & 3.70 & 3.32 \\
\hline 気 体，温 度( & 16 & 18 & 20 & 20 \\
\hline 気 体 圧 力 $\left(\mathrm{mmHg}^{2}\right)$ & 762 & 763 & 770 & 776 \\
\hline 放 電 時 間 (hr) & 4.0 & 4.0 & 4.0 & 4.0 \\
\hline 使用シクロへキサン量(g) & 58.15 & 114.34 & 181 & 228.27 \\
\hline 全生成物量 $(\mathrm{g})$ & 33.86 & 40.47 & 33.39 & 36.29 \\
\hline 反 応率 $(\%)$ & 58.2 & 35.4 & 18.5 & 15.9 \\
\hline 生 成 物 內訳 . & & & & \\
\hline (主生成物 (収率) (\%) & 64.2 & 70.0 & 71.9 & 74.5 \\
\hline 有機酸(アジピン酸) $(\%)$ & 15.1 & 6.5 & 6.0 & 5.2 \\
\hline 蒸 溜 残 泾(\%) & 20.7 & 23.5 & 22.1 & 20.3 \\
\hline 時間当り生成留 $(\mathrm{g} / \mathrm{hr})$ & 8.46 & 10.11 & 8.34 & 9.07 \\
\hline
\end{tabular}

符 4 表気体流速心影響 (シクローキサン高浱度り場合)

\begin{tabular}{|c|c|c|c|}
\hline $\begin{array}{l}\text { 条件及体流速 } \\
\text { খ゙結果 }\end{array}$ & 1.0 & 1.9 & 3.0 \\
\hline 一次電压 $(V)$ & 100 & 100 & 100 \\
\hline 一次需 流 $(A)$ & 3.7 & 3.5 & 3.7 \\
\hline 放 電 需 圧 $(\mathrm{kV})$ & 25 & 25 & 25 \\
\hline 放 電 電 流 $(\mathrm{mA})$ & 19.7 & 19.9 & 20.2 \\
\hline 放電管温度 $\left({ }^{\circ} \mathrm{C}\right)$ & $40 \sim 50$ & $40 \sim 50$ & $40 \sim 50$ \\
\hline 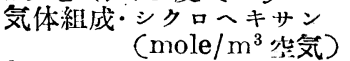 & 4.55 & 5.34 & 5.73 \\
\hline 気 体温度 $\left(^{\circ} \mathrm{C}\right)^{\circ}$ & 30 & 30 & 34 \\
\hline 気体圧 万 $\left(\mathrm{mmHg}^{2}\right)$ & 764 & 769 & 768 \\
\hline 放 電 時 問 $(\mathrm{hr})$ & 2.58 & 6.33 & 4.50 \\
\hline 使用シクロへキサン量(g) & 49.98 & 269.6 & 330.6 \\
\hline 全生成物 量 $(\mathrm{g})$ & 21.8 & 56.6 & 35.1 \\
\hline 反店率 $(\%)$ & 43.7 & 21.0 & 10.6 \\
\hline 生成物内訳 & & & \\
\hline (主生成物(収率) (\%) & 66.6 & 66.5 & 68.3 \\
\hline 有機酸(アジピン酸)(\%) & 12.1 & 16.1 & 10.2 \\
\hline 蒸 溜 残 渣 & 21.3 & 17.4 & 21.5 \\
\hline 時間当 $y$ 生成量 $(\mathrm{g} / \mathrm{hr})$ & 8.45 & 8.94 & 7.8 \\
\hline
\end{tabular}

これに比し収率は流速に比例して漸増する。従って反応 率欧び収率を調整する場合，全く次元の哄なった流速と 
電生のいずれを用いても良いとととなる。ここでゆら電 王は電流 (管内の電子濃度) に比例すると考六て取り扱 完るもので，工業化の場合は種々の点を考應すれば単位 反応管当りの印加電力を最大にして流速を加減する方が 適していると思利る。

シクロへキサン祳度の高低に拘わらず主生成物収率及 び単位時間当り(電力当り)の全生成物量は殆んど变ら ない。従ってシクロへキサンの高湛最組成を用いる場合 は印加電圧, 気体流速等の条件を適当に变化して行らこ とぶ必要である。

気体組成の他の要素即ち酸素濃度の变化については実 験の便宜上続いて報告する静的方法に扣いて行ったの でここでは省略する。

\section{放電管の長さの影鄉}

管の有効長を $55,123,200 \mathrm{~cm}$ と区分して用い(気体 の容積速度を一定 [67l $\cdot$ air $/ \mathrm{hr}]$ にすれば空間速度はそ れぞれ 4.56, 2.05, $1.25 \mathrm{Vol} / \mathrm{min} / \mathrm{Vol}$ ) て，その影響 を調べた。これは放電管内が均一な反応の塨であるか否

第 5 表 放電管の長さの影響

\begin{tabular}{|c|c|c|c|}
\hline 条件及び絬果 & 55 & 123 & 200 \\
\hline 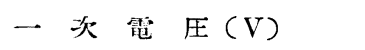 & 100 & 100 & 100 \\
\hline 一次電 流 $(A)$ & 1.6 & 2.7 & 4.41 \\
\hline 放 電 電 圧 $(\mathrm{kV})$ & 25 & 25 & 25 \\
\hline 放 電電 流 $(\mathrm{m} A)$ & 10.0 & 16.5 & 24.2 \\
\hline 放需管温度 $\left({ }^{\circ} \mathrm{C}\right)$ & $33 \sim 43$ & $43 \sim 53$ & $45 \sim 55$ \\
\hline 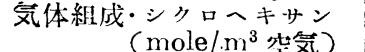 & 2.67 & 2.69 & 3.36 \\
\hline 気体流速 $(\mathrm{V} / \mathrm{min} / \mathrm{V})$ & 4.56 & 2.05 & 1.25 \\
\hline 気体温度 $\left({ }^{\circ} \mathrm{C}\right)$ & 15 & 15 & 15 \\
\hline 気 体圧力 $(\mathrm{mmHg})$ & 761 & 767 & 767 \\
\hline 放 電 時 間 $(\mathrm{hr})$ & 12.5 & 7.0 & 5.0 \\
\hline 使用シクロへキサン量 (g) & 179.5 & 100 & 90.63 \\
\hline 全生成物 显 $(\mathrm{g})$ & & & .77 \\
\hline 反応率 $(\%)$ & 13.5 & 29.6 & 41.7 \\
\hline 生成物內訳 & & & \\
\hline (主生成物(収率) (\%) & 75.3 & 62.2 & 57.6 \\
\hline 有機酸(アジピン酸)(\%) & 11.6 & 18.2 & 24.1 \\
\hline 蒸 溜 残 渣 $(\mathrm{g} / \mathrm{hr})$ & 13.1 & 19.6 & 18.3 \\
\hline 時間当り生成量 $(\mathrm{g} / \mathrm{hr})$ & 1.94 & 4.24 & 7.55 \\
\hline
\end{tabular}

か，又管壁を流下する生成物が途中に执いて副次反応を ぞの程度起しているかを明らかにする目的であるが，他 方工業用反応管の試作，設計の際にも阎当な管長を求め て置くことは必要でせる。その条件政び結果を第 5 琶に 掲げる。即ち反応率は管の辰さに比例して増加し，収率 は逆比例して漸減する状況は丁度気体流速の窓化によく 対応している。従ってこの放電反応においては管の長さ を気体法速の対応值に置きかえてとり扱って差し支えな いことが判った。管壁を流下する生成物も文殆んど变化 を受けていない点は注目に值する。

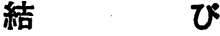

シクロヘキサンを放電により緩酸化してシクロへキサ ノール敢びシクローキサノンを合成する反応に执いて， 区応条件のうち，放電電圧, 放電管の長さ, 気体流速及び シクロへキサンの濃度を変化して反応を検討した結果，

1）放雪管一回通過当りに生成する全生成物の通過シ クロヘキサンに対する量比（反応率とすれば）は印加電 圧改び放電管の長さに比例し，又気体流速に逆比例して 著しく増加する。

2）全生成物中に含有されるシクロへキサノール及び シクロヘキサノンの量比（収率とすれば）は区応率の増 加に逆比例して多少減少する傾问が学る。このことは初 期生成物が長く放電管内に滞留しない活ど収率が良くな ることのように解される。

3) 同一条件で行った場合はシクロへキサン濃度の増 加は反応率を低下させるが，収率には殆んど影響を与え ていない。従って高濃度シクロへキサンを用いる場合は 印加電圧，気体流速等の調節により反応率の低下を防ぐ ことを考完る必要がある。

以上の事柄は次報以降任述べる本反応機構の解明烦 い極めて良く説明され，逆に又上述の結果が反応機構考 究に対しても側面的に役立っていることを岁らかじめ括 断りしで就く。

終りに本矿究を行らに当り終始御烈篤な御指導を賜わ った東京工業大学杉野喜一郎教授に対し深く感謝すると 共に，熱心に実験を援助された日本カーバイド工業株式 会社若林 徽氏に謝意を表する。な和研究費として交部 省科学試験砳究費う一部を使用したことを御報告する。

（昭和 27 年 4 月，電気化学会講演） 


\section{プルプロガリン類 似合成（第 1 報）}

村上 増雄・鈴木洸次郎・三島 英一

最近盛儿に研究されているトロポロン誘導体について は, 数多くのものが合成されているが，何れの方法も卜 ロポロン環を作ることが相当困難で女る。しかるにプル プロ劦りンだけはピロガロールを我溶液中で酸化するた けで簡単に合成されるのは與味女ることで女る。酸化郕 にはヨード酸塩 ${ }^{1)}$, クロム酸, 赤血塩, 電解, キノン等が 用いられる。プルプロガリンは赫绝素で Girard ${ }^{2)}$ が ピロガロールの酸化で得て扣り，のちに天然にも存在す ることが判っだう。この構造は最近になり，漸くベンジ トロポロン型の式が与兄られ，現在は構造が確定してい る)。(第1図 $A: R_{1}=\mathrm{OH}, \mathrm{R}_{2}=\mathrm{R}_{3}=\mathrm{R}_{4}=\mathrm{H}$ ) Willstätter ${ }^{5}$ によるとピロガロールモノメチルエーテルは酸 化してもプルプロガリン誘導体にはならないが，メトオ キシーーーキノンをピロガロールとエーテル中で混合する と，プルプロガリンモノメチルエーテルが得られる。又 Haworth ${ }^{6)}$ はピロガロールモノメチルェーテルに対し, ビロガロールと酸化郕を並行して加える方法で，比輘的 收量良くプルプロガリンモノメチルエーテルを得, 文同 様なす法でプルプロガリンカルボン酸を得ている。

これらの惊告より，著者等はプルプロガリンになるべ ンゼン部とトロポロン部を別個に考皇た。ピロガロール モノメチルエーテルがベンゼン部になり得ること及びフ

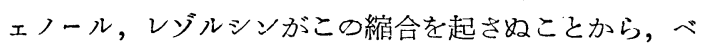
ンゼン部になるには 0 -位に 2 個の $\mathrm{OH}$ 基が存在する必

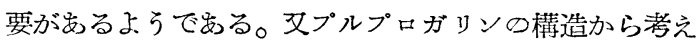
て $\mathrm{OH}$ 基に対して $0, m$ 位で縮合するからこの二つの 位置が空位でなければならないらしい。実際カテュール とピロガロールとの反応でベンゾトロポロン環を得た。

トロポロン部では隣り合った三個の $\mathrm{OH}$ 基が必要で 岕る。縮合がピロガロールの4 位で起るから，ピロガロ ールの5 置換体はトロポロン部にはなり得るがベンゼン

1) J. W.Evans, M. M. Dehn, J. Am. Chem. Soc. 52, 8647 (1930).

2) A. Girard, Ber. 2, 562 (1869).

3) M. Nierenstein, Biochem. J. 38, 373 (1914).

4) R. D. Haworth et al., J. Chem. Soc. 1950, 1631.

5) R. Willstätter, H. Heiss, Ann. 433, 17 (1923).

6) R. D. Haworth et al., J. Chem. Soc. 1951, 1318.
部にはなり難い。6 置換体はべンゼン部，トロポヒン部 の両部分になる可能性がある。

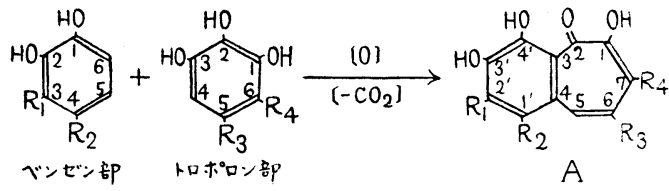

(ベンゼン部) (トロポロン部) (生 成 物) $\mathrm{R}_{1}=\mathrm{R}_{2}=\mathrm{H} ; \quad \mathrm{R}_{3}=\mathrm{R}_{4}=\mathrm{H} \longrightarrow \mathrm{I}$ 融点187 $28^{\circ}$ $\mathrm{R}_{1}=\mathrm{R}_{2}=\mathrm{H} ; \quad \mathrm{R}_{3}=\mathrm{CO}_{2} \mathrm{H}, \mathrm{R}_{4}=\mathrm{H} \rightarrow$ II 融点 $>300^{\circ}$ $\mathrm{R}_{1}=\mathrm{H}, \mathrm{R}_{2}=\mathrm{Cl} ; \quad \mathrm{R}_{3}=\mathrm{CO}_{2} \mathrm{H}, \mathrm{R}_{4}=\mathrm{H} \rightarrow$ III 融点 $>300^{\circ}$ $\mathrm{R}_{1}=\mathrm{H}, \mathrm{R}_{2}=\mathrm{PhEt} ; \mathrm{R}_{3}=\mathrm{CO}_{2} \mathrm{H}, \mathrm{R}_{4}=\mathrm{H} \rightarrow \mathrm{IV}$. 融点 $245 \sim 6^{\circ}$ $\mathrm{R}_{1}=\mathrm{OH}, \mathrm{R}_{2}=\mathrm{Et} ; \quad \mathrm{R}_{3}=\mathrm{H}, \quad \mathrm{R}_{4}=\mathrm{Et} \rightarrow \mathrm{V}$ 融点 $145 \sim \hbar^{\circ}$ 第 1 図

以上のことから，5，6位の空いたカテュール誘導体 とピロガロール5 蓪換体を用いたならば，反応は単一方 向に進むのではないか，といらことが予想されるが，䒠 験を行って見ると反応は円沮に行われるらしく沈澱物り 比較的精製乙易い(例， II IV )。

カテコール誘導体とピロガロール誘導体とを反応させ て数種のプルプロガリン類似物 $(\mathrm{I} \sim \mathrm{V})$ を得た。

次にハイドロキノン文び $p$-キノンとピロガロールの 酸化縮合を試みた。ハイドロキノンの場合は黒褐色沈敩 物と少量のプルプロガリン反び慬少量の融点 $248^{\circ}$ 一 $251^{\circ} \mathrm{C}$ の黒赤色針状晶が得られ $p$-キノンでは黒褐色沈 測物と少量のハイドロキノン，キンヒドロン 及び融点 $249^{\circ} \sim 251^{\circ} \mathrm{C}$ の黑赤色釬状結晶を得て，プルプロガりン は確認出来なかった。この黒赤色釬状絓晶は元素分析区 び赤外線吸収ス・゚クトルの結果から四の構造を持ってい るのではなかららかと考完られる。

ピロガロールの水溶液に $p$-キ，ンのみを加忩る之ー ルプッガリンが生成してに得られない。

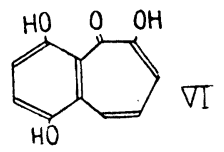

第次 